\title{
Daignosis of Staphylococcus aureus mastitis in bovine in Al- Najaf province by using Polymerases chain reaction (PCR)
}

\author{
N. A.Al- Anbagi \\ Q. H.kshash \\ Coll. of Vet. Med./ Unive. of Al-Kufa \\ Coll. of Vet. Med./ Unive.of Al-Qadyssia
}

\begin{abstract}
This study was conducted to collect 388 milk samples from cows at different villages and townships in Al-Najaf province to examine about Staphylococcus aureus mastitis .CMT was used for subclinical mastitis screening ,212(54.6\%) milk samples were mastitic .The molecular method (PCR assay) was used to detected the presence $(g l p F)$ gene in classically diagnosed S.aureus, which appeared that 38(92.6\%) S.aureus mastitis as $13(32.5 \%)$ clinical and 25(14.5\%) subclinical mastitis .There was high significant incidence of Staphylococcus aureus mastitis in left posterior udder quarter rather than others quarters.
\end{abstract}

Key word: S.aureus, bovine mastitis, glpf gene

\section{Introduction}

Mastitis remains the most common disease of dairy cattle, causing the biggest economic losses to the dairy industry ( 1 ). S.aureus is among the most common etiologic agents of bovine mastitis ( 2 ) Staphylococcus aureus is a major pathogen in dairy cattle mastitis $(3,4,5)$, it causes big financial/economic loss to the dairy industry worldwide, mainly due to reduced milk production and the need to discard contaminated milk (6,7 ).Iraq have many researches were done on mastitis in cows' herds for detection of causative agents, (8 ) were isolated just one isolate
S.aureus from 29 cows suffered from acute mastitis in cows' herd in Al-Sulaymaniya governorate during two years (19781979),While (9) recorded the highest percentage to S.aureus isolates (36\%). (10) had been revealed that S.aureus was isolated at $7.64 \%$. (11) at Al-Nasir station of cows, She resulted that S.aureus mastitis was (28.73\%) . (12) show the highest results of isolation of S.aureus from mastitic cows were (58\%), while (13) found the percentage of Staphylococcus aureus mastitis in cows in Ninevah governorate was $55 \%$.

\section{Materials and methods}

Materials

\section{Cultures media:-}

1. Blood agar base :

2.Nutrient agar:

3. Mannitol Salt Agar :

4. Brain Heart Infusion agar:

5. Nutrient Broth:

6A. Urea Agar: All media were prepared according to information's of manufactured company .

Reagents :

1. Catalase reagent: According to (14)
2.Oxidase reagent:According to (15)

3.CaliforniaMastitisTest (CMT):It

used for detection a subclinical

mastitis (16)

4.Coagulase reagent ( rabbit plasma ): Bacton, Dickinson Company (Spain)

5. Gram Stain :It Prepared according to (15) .

6. Urea solution $(20 \%)$ :

Commercial kits:The commercial kits used in the present study are shown in Table (1)and its appendices, as follow:-

Table (1): Commercial kits used in the present study 
$\begin{array}{llll}\text { AL-Qadisiya Journal of Vet.Med.Sci. } & \text { Vol./12 } & \text { No./2 } & 2013\end{array}$

\begin{tabular}{|r||r|r|}
\hline No. & Types of kits & Source \\
\hline \hline 1 & DNA extraction Kit(1) & Geneid/Korea \\
\hline \hline 2 & Green master mix 2X Kit(2) & BIONEER/Korea \\
\hline \hline 3 & Primers(3) & BIONEER/Korea \\
\hline
\end{tabular}

2. Green master mix consist of :-

\begin{tabular}{|r|r|}
\hline 1 & DNA polymerase enzyme (Taq) \\
\hline \hline 2 & $\mathrm{dNTPs}$ \\
\hline \hline 3 & $\mathrm{MgCl} 2$ \\
\hline \hline 4 & PCR loading buffer \\
\hline \hline 5 & PCR reaction buffer (pH 8.3) \\
\hline
\end{tabular}

3.Primers include from:

\begin{tabular}{|c|c|c|c|c|}
\hline $\begin{array}{l}\text { Target } \\
\text { gene }\end{array}$ & Oligonucleotide & $\overline{5^{\prime}-3^{\prime} \text { Sequence }}$ & $\begin{array}{r}\text { Product } \\
\text { length }\end{array}$ & Reference \\
\hline \multirow[t]{2}{*}{$\overline{g l p F}$} & $\bar{F}$ & caatgggtgtgtttgc tgtc & \multirow[t]{2}{*}{$223 \mathrm{bp}$} & \multirow[t]{2}{*}{ (In this study) } \\
\hline & $\mathrm{R}$ & agccggtgctgta ga gaaaa & & \\
\hline
\end{tabular}

\section{Methods :}

\section{Clinical study :-}

Three hindered eighty eight (388) milk samples collected from clinical mastitic cows( 40 ) and (174) from cows appears healthy (without signs of mastitis ) were taken From different areas of AlNajaf province. Milk samples were collected in sterile tubes ( 2 tubes) for each sample (one for CMT and physical exam and another for bacteriological test) and a septic technique used for milk samples collection. The procedure for milk sample collection according to (17). The samples were transported to the laboratory in ALQadissiya University by cooling box.

2. Tests that used for examination of milk samples:

\section{A. California Mastitis Test (CMT)}

At laboratory of veterinary medicine collage Al- Qadissiya University , normal milk samples were examined by CMT(California Mastitis Test) according to (18) .

\section{B. Bacterial Culture :}

All milk samples from clinical mastitis and another samples which gave a positive reaction with ( $\mathrm{CMT}$ ) were submitted to centrifugation at $3000 \mathrm{rpm} / 15$ minutes, and the precipitate was cultured on Blood agar ,Nutrient agar by streaking method and then were incubated at $37 \mathrm{C}^{\circ} / 48 \mathrm{hrs}$, diagnosis depend on morphological character (shape ,color and size) of colony, then examined via gram stain, then after that the suspected colonies were subculture on selective and differentiate media then incubated at $37 \mathrm{C}^{\circ} \mathrm{f}$ 48 hrs.

C.Gram stain : According to (19).

D. Biochemical Tests:

1.Catalase test: (20).

2.Coagulase test $(21,22)$.

3.Oxidase Test (19).

4.Urease test : (23).

5.Heamolysis Test: (24) .

E.Confirmative diagnosis of staphylococcus aureus by PCR by housekeeping gene ( $\mathrm{l} l \mathrm{pF}$ )

The Staphylococcus aureus isolates which examine according classical methods may be submitted to Polymerase chain reaction assay was performed for confirmative detection of staphylococcus aureus by Housekeeping gene glycerol 
kinase ( $g l p F$ gene). All bacterial isolates were confirmated by PCR assay using (glycerol kinase ) as conseveved gene in detection Staphylococcus aureus bacterium.This assay was done according to method described by $(25,26,27,28)$.

\section{Primer}

The oligonucleotide primers for detection of Staphylococcus aureus $(g l p F)$ gene were designed in this study. The primer provided from (Bioneer, Korea) company as following in table( 2) .

Table (2): The Primers and their sequences and PCR product size.

\begin{tabular}{|l|l|l|c|}
\hline \multirow{2}{*}{ Primer } & \multicolumn{2}{|c|}{ Sequence } & \multirow{2}{*}{ Product size } \\
\hline \multirow{2}{*}{ glpf } & F & caatgggtgtgttgctgtc & \multirow{2}{*}{$233 \mathrm{bp}$} \\
\cline { 2 - 3 } & $\mathrm{R}$ & agccggtgctgtagagaaaa & \\
\hline
\end{tabular}

\section{Genomic DNA extraction}

Genomic DNA of staphylococcus aureus isolate was extracted by using Genomic DNA Mini Kit, according to manufactured company, The extracted DNA was checked electrophoresis using $1.5 \%$ agarose gel.

\section{Preparation of PCR master mix}

The PCR master mix was prepared by using (AccuPower PCR PreMix Kit) and this master mix done according to company instructions.

\section{PCR thermocycler conditions}

The PCR thermocycler conditions of $\mathrm{glpF}$ primer . performed by using optimize PCR protocol writer online and done in convential PCR thermocycler system as following table

Table (3) :protocol steps for glpF primer in PCR assay

\begin{tabular}{|c|c|c|c|}
\hline PCR cycle & Repeat cycle & Temp. & Time \\
\hline $\begin{array}{c}\text { Initial } \\
\text { denaturation }\end{array}$ & 1 & $94 \mathrm{C}^{\circ}$ & $5 \min$ \\
\hline Denaturation & \multirow{3}{*}{30} & $72 \mathrm{C}^{\circ}$ & $30 \mathrm{sec}$ \\
\hline Annealing & & $55 \mathrm{C}^{\circ}$ & $30 \mathrm{sec}$ \\
\hline Extension & & $72 \mathrm{C}^{\circ}$ & $30 \mathrm{sec}$ \\
\hline Final extension & 1 & $72 \mathrm{C}^{\circ}$ & $5 \min$ \\
\hline Hold & - & $4 \mathrm{C}^{\circ}$ & forever \\
\hline
\end{tabular}

5.PCR product analysis :The PCR products of for all genes was separation by electrophoresis using $1.5 \%$ agarose gel . statistical analysis
The Chi-square test was applied to determine the statistical significance of the data. $P$ value of $<0.05$ was considered significant

\section{Bacterial isolation}

\section{Results}


In this study, ( 44) suspected $S$. aureus isolates were detected their colonies morphologically on blood agar as smooth, yellow, white Colonies of 1 to 2 $\mathrm{mm}$ in diameter. All $S$. aureus colonies showed $\beta$-hemolysis and staining showed gram positive cocci arranged in clusters or spread of bacteria as spherical single cocci, diplococci, but the predominant shape was grape-like clusters of blue color under light microscope, and those mentioned features were characteristics features of staphylococci bacteria. Suspected S.aureus isolates were subcultured on mannitol salt agar for purification (selective agar containing $7.5 \%$ Nacl that inhibit all bacteria but not S.aureus), the colonies appeared as rounded, smooth convex colonies yellowish in color disseminated to the background of the agar indicated fermentation of mannitol sugar.

\section{Biochemical Characteristics}

Performing additional biochemical tests on suspected colonies for complete identification of staphylococci which revealed that 41 isolates out of 44 suspected isolate may be S.aureus as in table (4).

Table (4): Biochemical test of S.aures isolates

\begin{tabular}{||l||l||l||l||l||}
\hline $\begin{array}{l}\text { Suspected } \\
\text { S.aureus becteria }\end{array}$ & $\begin{array}{l}\text { Catalase } \\
+\end{array}$ & $\begin{array}{l}\text { Oxidase } \\
+\end{array}$ & $\begin{array}{l}\text { Coagulase } \\
+\end{array}$ & + \\
\hline \hline 44 & 41 & 41 & 41 \\
\hline
\end{tabular}

\section{Polymerases chain reaction results genomic DNA extraction}

DNA from over night broth bacterial cultured was extracted by Geneiad Bacteria Genomic DNA Extraction Kit,
Bioflux. The extracted DNA was checked by electrophoresis using 1.5\% agarose gel. Genomic DNA (bands) were visualized by UV light as system showed in figure (1).

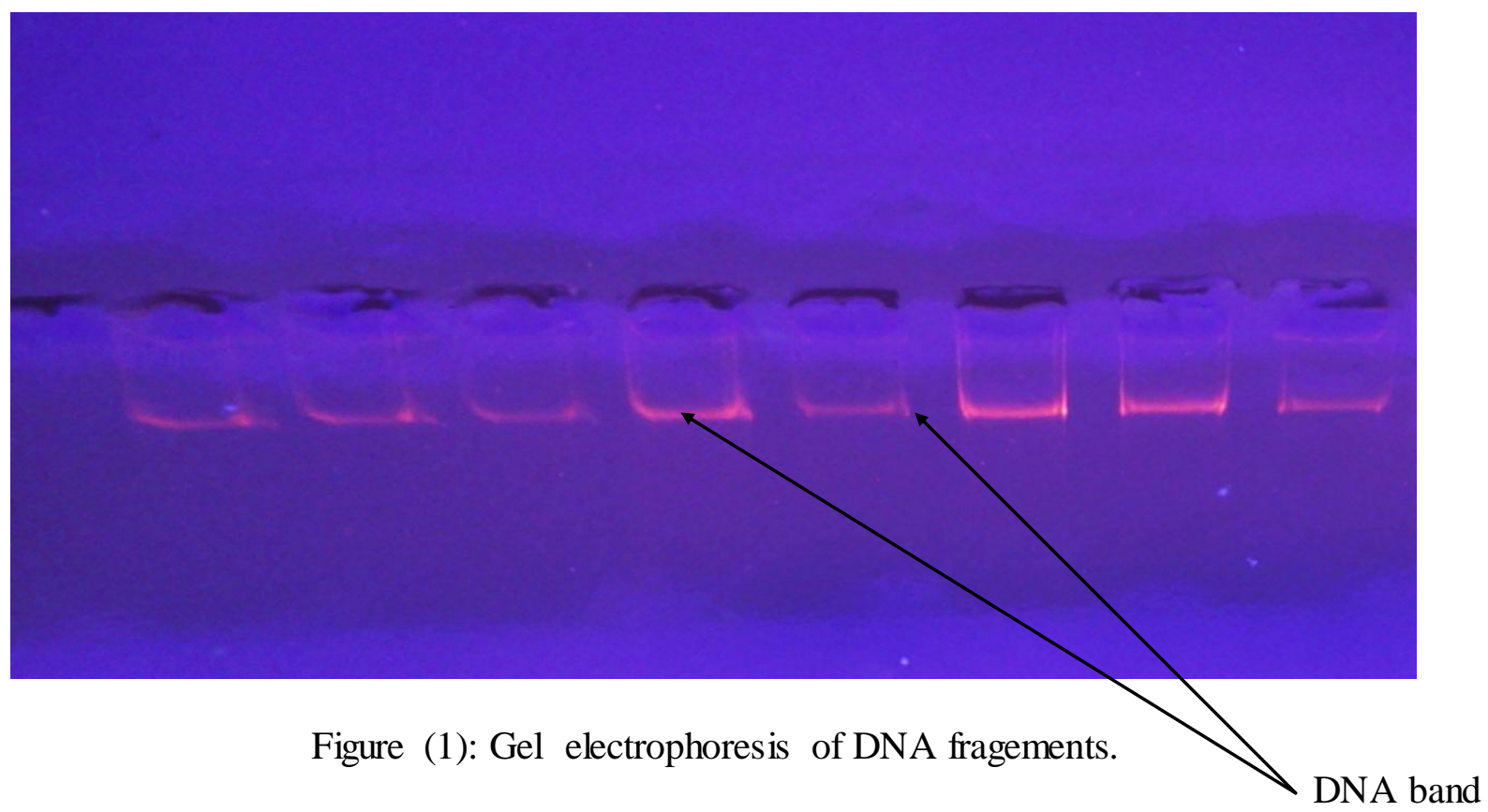


Confirmation diagnosis staphylococcus aureus by detection Housekeeping ( $g l p F$ ) gene by PCR

All bacterial isolates ( 44) which isolated from blood agar according type of hemolysis and gram stain these isolates cultured on selective media (manitol salt agar) and diagnose according classical method as(41) S.aureus isolates were identified by PCR that revealed $38(92.6 \%)$ S.aureus isolates were detected which have $(g l p F)$ gene with product size 223bp. Table (5), Figure (2).

Table( 5):Detection S.aureus by classical methods and PCR technique

\begin{tabular}{|c|c|c|c|c|}
\hline $\begin{array}{r}\text { Isolates numbers } \\
\text { Suspected S.aureus }\end{array}$ & \multicolumn{2}{|c|}{$\begin{array}{l}\text { Classical diagnostic } \\
\text { methods of S.aureus }\end{array}$} & \multicolumn{2}{|c|}{$\begin{array}{l}\text { Confirm detection by PCR } \\
\text { technique of S.aureus }\end{array}$} \\
\hline$\overline{44}$ & $\overline{441}$ & 888.1 & $\overline{38}$ & $\bar{~} 992.6$ \\
\hline
\end{tabular}

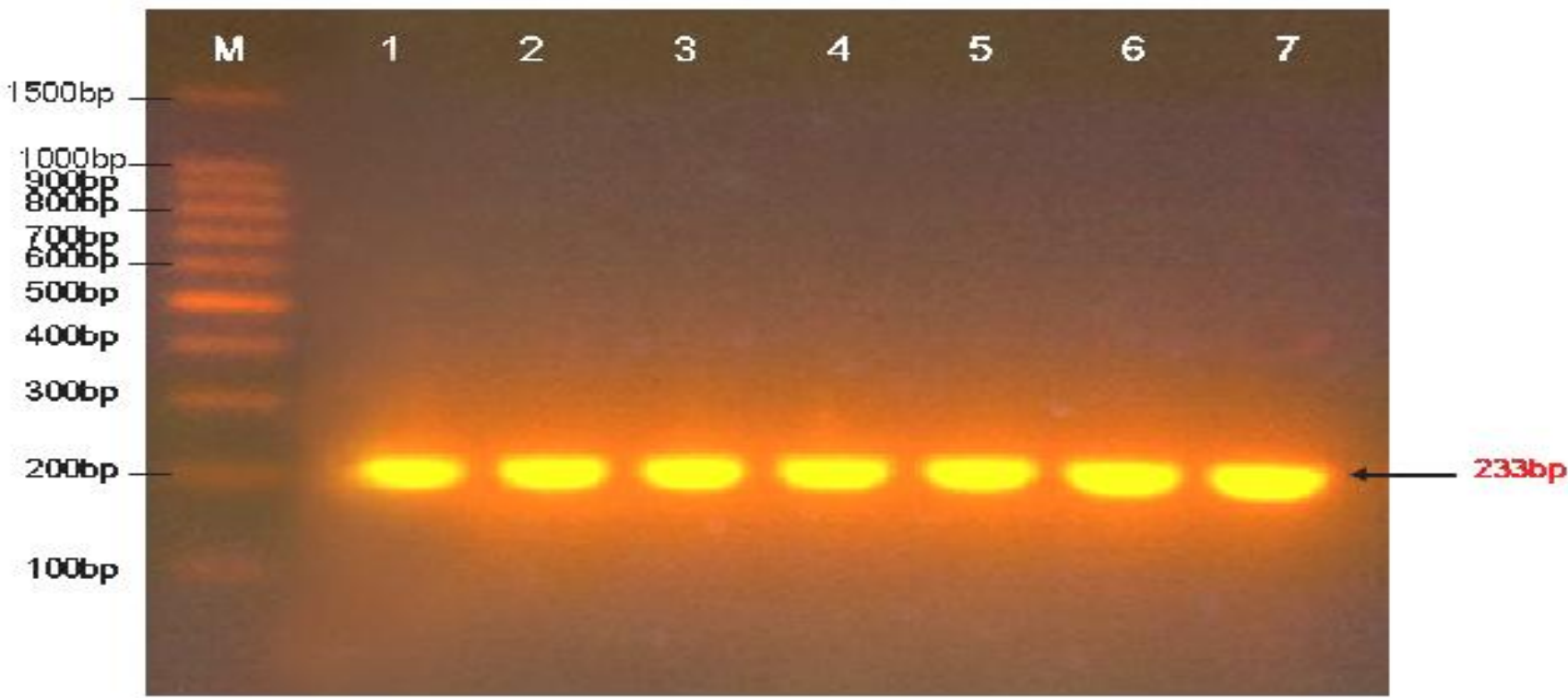

Figuer (2): Gel electrophoresis of DNA fragements $223 \mathrm{bp}$ amplified fragment of $g l f a$ gene among examined S.aureus isolates.

Out of 388milk samples which collected from cows in some villages and townships of the AL-Najaf province ,there were 212 milk samples $(54.6 \%)$ are infected (mastitic) as 40(18.8\%) clinical mastitis and $172(81.1 \%)$ subclincal mastitis .Table (6) . 
Table (6): Percentage of clinical and subclinical of examined milk samples.

\begin{tabular}{|c|c|c|c|c|c|c|}
\hline $\begin{array}{r}\text { Numbers of } \\
\text { examined milk } \\
\text { samples } \\
\end{array}$ & \multicolumn{2}{|c|}{$\begin{array}{r}\text { Mastitis milk } \\
\text { samples }\end{array}$} & \multicolumn{2}{|c|}{ Clinical Mastitis } & \multicolumn{2}{|c|}{ Subclinical Mastitis } \\
\hline \multirow{2}{*}{388} & $\overline{\mathrm{No}}$ & $\bar{~} \%$ & No. & $\bar{~} \%$ & No. & $\%$ \\
\hline & 212 & 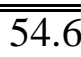 & $\overline{40}$ & $\overline{18.8 \mathrm{a}}$ & 172 & $81.1 \mathrm{~b}$ \\
\hline
\end{tabular}

*The different letters refers to significant differences at $(\mathrm{p}<0.05)$

Percentage of S.aureus and CoNS in clinical and subclinical mastitis :-

But staph mastitis was classified into S.aureus mastitis $38(17.9 \%)$ as $13(32.5 \%)$ clinical and $25(14.5 \%)$ subclinical form

Table (7): Percentage of S.aureus and CoNS mastitis

\begin{tabular}{||l||l||l|l||l|l||}
\hline \multirow{2}{*}{ Mastitis form } & \multirow{2}{*}{ No. } & \multicolumn{2}{|l||}{ S.aureus } & \multicolumn{2}{l||}{ CoNS } \\
\cline { 4 - 6 } & No. & $\%$ & No. & $\%$ \\
\hline \hline Clinical mastitis & 40 & 13 & $\begin{array}{l}32.5 \\
\text { Aa }\end{array}$ & 2 & $\begin{array}{l}5 \\
\text { bA }\end{array}$ \\
\hline \hline Subclinical Mastitis & 172 & 25 & $\begin{array}{l}14.5 \\
\text { Ba }\end{array}$ & 91 & $\begin{array}{l}52.9 \\
\text { bB }\end{array}$ \\
\hline \hline Total & 212 & 38 & $17.9 \mathrm{a}$ & 93 & $43.8 \mathrm{~b}$ \\
\hline
\end{tabular}

*CoNS :Coagulase Negative Staphylococci

$*$ The different letters refers to significant differences at $(p<0.05)$

Relationship between the isolation of S.aureus and Udder quarters

S.aureus was isolated from different udder quarters ,the posterior udder quarters were recorded the higher percentage of Table(8) :Relationship between the isolation of S.aureus and Udder quarters of examined cows

\begin{tabular}{||l||l||r|}
\hline Udder quarters & \multicolumn{1}{||}{ S.aureus } \\
\hline \hline Right anterior RA & 5 & $\%$ \\
\hline \hline Right posterior RP & 7 & $13.1 \mathrm{a}$ \\
\hline \hline Left anterior LA & 10 & $18.4 \mathrm{a} \mathrm{b}$ \\
\hline Left posterior LP & 16 & $26.3 \mathrm{~b}$ \\
\hline \hline Total & 38 & $42.1 \mathrm{c}$ \\
\hline
\end{tabular}

$*$ The different letters refers to significant differences at $(\mathrm{p}<0.05)$ 


\section{Discussion}

\section{prevalence and occurrence of bovine mastitis}

Mastitis is the most important worldwide disease in dairy milk production (29), and it is notoriously difficult to estimate the losses associated with clinical and subclinical mastitis, which arise from the costs of treatment, culling ,death and decreased milk production and constituent quality (30) . Bovine mastitis continues to cause a huge economic burden to the dairy industry (31) .Results from our study showed that the percentage of bovine mastitis was $54.6 \%$ which similar to percentage of bovine mastitis were found by (32) was $52.4 \%$, while our results contradict all (33) and (34) in Iraq were found percentage of bovine mastitis $77.5 \%$ and $77.7 \%$ respectively . This different of mastitis percentage due to several factors as season of study, type of housing , breed, age of animals (17).According our knowledge may be due to laboratory technique and degree of contamination found and sanitary measurement that applied or not indifferent herds were effective.The present study were showed that the percentage of clinical mastitis 18.8 $\%$ which accordance with (35) who examined 223 mastitic milk samples in Egypt and found $21.5 \%$ were clinical mastitis ,while (36) were founded $22.50 \%$ clinical mastitis in Assiut, Egypt. Our results lower than percentage by (9) $33.01 \%$ in Iraq .The variation in incidences of clinical mastitis may be due to many causes as the type and severity of the causative agent,size of herd and sampling collectionary (randomly or selectivity ) also that high milk producing cows are more susceptible and the nutritionary status of the herd more effective (17). Results from accurate study ,the subclinical mastitis percentage was $81.1 \%$ which was like the result of (37) in Mosul as $80.85 \%$ and also nearest with the result of (38) in a percentage $77 \%$, (33) $77.6 \%$ in Iraq and
87.2\% in Egypt reported by (35) while unlike with the result the study by (39) with a percentage of $92.3 \%$,the discrepancy depend on environment factor as contamination, we thought due to milkier hygiene and may be external parasites as ticks which cause mini wounds result from tick bite as well as that coagulase negative Staphylococci (CoNS) found as normal flora on teat skin, all that stimulate mastitis occurrence. The prevalence of mastitis effected by extensive investigation and research of mastitis etiology may be capable of helping to provide an important and optimistic approach to control this disease (40) .

Isolation S.aureues from clinical and subclinical mastitis

S.aureus isolated from clinical mastitis in this study $(32.5 \%)$ was higher than that was earlier reported by (41) (20.59\%) from Abu-Ghraib zone from cows suffering acute mastitis in Baghdad government and (42) in Estonia found $20 \%$ from clinical mastitis samples were positive to S.aureus .This result comparable with Swedish Study $(28.3 \%)$ S.aureus isolated from clinical mastitis by (43) but our result was lower from another studies as (44) who found that $54.4 \%$ from clinical bovine mastitis were +ve to S.aureus infection and (12) which conducted to the highest results in isolation of S.aureus from mastitic cows; she found that out of 48 milk samples from acute cases there were 28 (58\%) S.aureus +ve isolates.Subclinical Staphylococcus aureus mastitis was $14.5 \%$. Which was in similar to the result (16.6\%) as obtained by (45) and closed to the range of S.aureus isolated from subclinical mastitis (12-37\%) in England, Spain and USA $(46,47)$ and in Sweden( $19 \%$ ) reported by (48). Substantial differences were found in result obtained from another studies (44.44\%),(44.03\%), $(41 \%),(6 \%)$ by (49), (50), (40) and (51) respectively. We observed there clear differences in percentages of isolate $S$. 
aureus in clinical and sub clinical mastitis of our study compare with another studies ,there may be for more than reason as possible reasons for bacteriologically negative findings in milk samples could be the presence of antibacterial substances in the milk that lead to a decrease in the viability of bacteria in the culture (52), or failures in conventional culture compared with identification of bacteria using the realtime polymerase chain reaction (53), growth of staphylococci was inhibited to a lower extent by lactoferrin which found in bovine milk $(54,55)$ which effect on percentage of

\section{References}

1. Halasa, T.; K. Huijps; O. Østerås, and H. Hogeveen. (2007). Economic effects of bovine mastitis and mastitis management: A review Vet. Q. , (29):18-31.

2. Barkema, H. W.; Green, M. J.; Bradley, A. J. and Zadoks, R. $\mathrm{N}(2009)$. The role of contagious disease in udder health. J. Dairy Sci.,(92): 4717-4729.

3. Waage, S.; Mørk, T.; Røros, A.; Aasland, D.; Hunshamar, A.and Odegaard, A.S., (1998). Bacteria associated with clinical mastitis in dairy heifers. J. Dairy Sci. ,(82): 712-719.

4. Tenhagen, B.; Koster ,G.; Wallmann, J., and Heuwieser, W. (2006). Prevalence of mastitis pathogens and their resistance against antimicrobial agents in dairy cows in Brandenburg, Germany. J. Dairy Sci. ,(89):2542.

5. Piepers, S.; De Meulemeester, L.; de Kruif, A.; Opsomer, G.; Barkema, H., and De Vliegher, S. (2007). Prevalence and distribution of mastitis pathogens in subclinically infected dairy cows in Flanders, Belgium. J. Dairy Res. (74):478.

6. Miller, G. Y.; Bartlett, P. C.; Lance, S. E.; Anderson, J. and Heider L. E., (1993).Costs of clinical mastitis bacterial isolation. We thought a mount, type and right selection of antibacterial which used also available professional veterinarian service and culture and knowledge of owner, all these factors effect on prevalence. In this study, the number of isolates from left hindquarter higher than other quarters, which is similar to previous reports by $(10,33)$ which was attributed to normal laying down of cow and that caused attachment of the posterior quarters with bed and also posterior quarters can contaminated by feces on hindlegs, tail of cow and uterus secretion $(56,57,17)$. and mastitis prevention in dairy herds. J. Am. Vet. Med. Assoc., (202): 1230-1236.

7. Seegers, H.;Fourichon, C. and Beaudeau, F. (2003).Production effects related to mastitis and mastitis economics in dairy cattle herds. Vet. Res., (34): 475-491.

8. Metwally, A.A.; Al-Khaffaf, S.T.; Majeid, L.A. and Othman, A.Y. (1981). Some studies on mastitis in cattle. Zanco, Series., (7): 2541.

9. Yass, A.A.; Yousif, A.A. and AlGraibawi, M.A. (1992).A study of the incidence of clinical mastitis in dairy cows. Iraqi J. Vet. Med.,( 6):12-21.

10. Al-Dulimy, W.A.G. (2004). Study on some aerobic bacterial causes of clinical mastitis in cows and the causes of some treatment failure. M. Sc. Thesis - College of Veterinary Medicine - Baghdad University.

11. Al-Marsoomy, H.M.M. (2007).Isolation and identification some bacterial causes of bovine mastitis and the inhibitory role of Lactobacillus and their products on Staphylococcus aureus growth. M.Sc. Thesis - College of 
Veterinary Medicine - Baghdad University.

12. Al-Kafaji, N.A.A. (2008). Experimental study for determination the effect of Plantago lanceolata and Eugenia caryophyllus alcoholic and watery extracts in the infection of mammary gland of mice by Staphylococcus aureus. M.Sc. Thesis- College of Veterinary Medicine - Baghdad University.

13. Sheet,.O.H. (2011). Isolation of Staphylococcus aureus from ruminant $\mathrm{s}$ milk and their resistance to antibiotic in Ninevah governorate. Iraq. J. Vet. Medi., 24(2): 109-114.

14. MacFaddin, J. F. (2000). Biochemical Tests for Identification of Medical Bacteria 3rd ed. Lippincott Williams and Wilkins, USA.

15. Quinn, P. J.; Carter, M. E.; Markey, B. K. and Carter, G. R. (1998). Clinical Veterinary Microbiology. London: M.Wolfe. Reprint, 327366.

16. Colles ,E.H.(1986) .Veterinary Clinical pathology .W.B.Saunders Company ,Philadelphia .USA .

17. Radostitis,O.M;Gay.C.C;Hinchliff,K. W.andConstable,P.D.(2007).Veter inary medicine a Texet book of the diseases of cattle, horse, sheep,pigs and got 10 Edition London:W.Saunder Compnay Limited.

18. 18.Schalm, W.; Carroll, E. J. and Jain, N. C. (1971). Bovine Mastitis. Philadelphia PA: Lea and Febiger .

19. Jawetz ,E.; Melnick, J.L. and Adelberg, E.A.(2001). Medical Microbiology $2^{\text {nd }} \quad \mathrm{Ed}$.Appleton and Large Garden Comp.U.S.A.

20. Forbes , B.A.; Sahm,D.F.and Weissfield ,A.S.(2002).Baily \&Scott s, Diagnostic Microbiology.11Ed .Mosby.
21. Cruickshank, R.; Duguid, J.P.; Marmion, B. and Swain, R.H. (1975). "Medical Micro-biology, A Guide to the Laboratory Diagnosis and Control of Infection" $12^{\text {th }}$ Ed. Vol. 2. The Practice of Medical Microbiology. Churchill Livingstone. Edinburgh, London and New York, 170-189.

22. Holt, J.G.; Krieg, N.R.; N.R.; Sneath; P.H.A.; Staley, J.T. and Williams, S.T. (1993). Bergey's Manual of Determinative $\quad$ Bacteriology. $\quad 9^{\text {th }}$ Ed. Baltimore.

23. Collee, J. G.; Fraser, A. G.; Marion, B. P. and Simmons, A. (1996). Mackie and McCaraty Practical Medical

Microbiology. $14^{\text {th }}$ ed.Longman Singapore. 131-149.

24. Cowan ,S.T.(1985). Cowan and Steels manual for identification of medical bacteria , $2^{\text {nd }} \mathrm{Ed}$ .Cambridge Uni.press.U.K.

25. Enright, M. C., N. P. J. Day, C. E. Davies, S. J. Peacock, and B. G. Spratt. (2000). Multilocus sequence typing for characterization of methicillinresistant and methicillinsusceptible clones of Staphylococcus aureus. J. Clin. Microbiol. 38:1008-1015.

26. Mason,W. J.; Blevins, J. S.; Beenken, K.;Wibowo, N.; Ojha, N., \& Smeltzer, M. S. (2001). Multiplex PCR protocol for the diagnosis of staphylococcal infection. J. Clin .Microbiol.,(39): 3332-3338.

27. Louie, L.; Goodfellow, J.; Mathieu, P.; Glatt, A.; Louie, M.and Simor, A. E. (2002):Rapid detection of methicillin-resistant staphylococci from blood culture bottles by using a multiplex PCR assay. J Clin Microbiol, 40, 2786-2790.

28. Maes, N.; Magdalena, J.; Rottiers, S.; De Gheldre, Y. and Struelens, M. 
J. (2002).Evaluation of a triplex

PCR assay to discriminate

Staphylococcus aureus from coagulase-negative staphylococci and determine methicillin resistance from blood cultures. J .Clin .Microbiol.,(40):1514-1517.

29. Kossaibati ,M.A.; Esslemont, R.J. (1997). The costs of production in dairy diseases herds in England. Vet. J. ,(154): 41-51.

30. Bradley, A .(2002).Bovine mastitis: an evolving disease. Vet. J. ,(164): 116-128.

31. Sawant, A.A.; Gillespie ,B.E. and. Oliver ,S.P.( 2009).antimicrobial susceptibility of coagulase negative staphylococcus species isolated from bovine milk. Vet. Microbial.,(134):73-81.

32. Gianneechini, R.; Concha,C.; R. ;Rivero,RI. ;Delucci,I., J. ;Moreno ,I.(2002). Occurrence of clinical and sub-Clinical mastitis in dairy herds in the west littoral region in Uruguay. Acta vet. scand. , 43 (4) :221-230.

33. Shekhan, M. I.( 2011). Sub Clinical and Clinical Staphylococcal Bovine Mastitis in AL-Diwaniyia province Thesis. M.S.c. Vet. Med. College. University of ALQadissiya.

34. Amin,W.(2001): Mastitis in Cows :Continuous problem in dairy cattle of Iraqi farm diagnosis and control.J.Iraq.Vet.Sci.,14(1 ）: 110118.

35. Asfour, H and Darwish, S.(2011). phenotypic and genotypic detection of both mecA-blaZ genes mediated B-lactam resistance in staphylococcus strain isolated from bovine mastitis . Global veterinaria.J.6(1):39-50.

36. Sayed ,M. and Abdel Rady,A.(2008). Acute Clinically Mastitic Animals in villages of Assiut Governance:
Diagnosis and Treatment.

Veterinary World, 1(9): 261-264.

37. Mahmmoud, E.N. and Shamoon G.N. (2009).isolation and identification of coagulase -negative staphylococci and detection of virulent factors in bovine mastitis .Iraqi .J.Vet.Sci., 23(2) ,university of Mosul .Mosul,Iraq.

38. Fawzia, A.A. ; Mohammed, H.K. and Rahman, K.M.(2002). Microboilogical study of subclinical mastitis of cows in Basrah city .Al- Qadissiya J.Vet.Med.Sci.,1(2):44-49.

39. Ahlner,S (2003): Prevalence of subclinical mastitis in Uruguay. $\mathrm{PhD}$ thesis . National Veterinary Institute, mastitis section 25-26.

40. Cheng, D.; Yuan Zhu ,S.; Yin, Z.; Ding, W.; Mu, Z., Su ,Z. and Sun, H.(2010). Prevalence of bacterial infection responsible for bovine Mastitis. African Journal of Microbiology Research. ,4 (11) :1110-1116.

41. Al-Ani,M.(2009). Immunopathological Study of Staphylococcus aureus Isolated from Bovine Mastitis M.S.c.Thesis Vet.Med. College. Baghdad University.

42. Kalmus, P.: Aasmäe, B. ; Kärssin, A.; Orro,T, and Kask,K.(2011). Udder pathogens and their resistance to antimicrobial agents in dairy cows in Estonia. Acta Veterinaria Scandinavica, 53(4):2-7.

43. Bengtsson, B.; Unnerstad, H. E.; Ekman, T.; Artursson, K.; NilssonOst, M. and Persson Waller, K.(2008).Antimicrobial susceptibility of udder pathogens from cases of acute clinical mastitis in dairy cows. VETMIC, 42-54.

44. Al-Khatib, G. and Al-Bassam, L. (1979). Report on isolation and identification on different 
pathogens from clinical cases.

Iraqi J. Vet. Med., 3: 109-120.

45. Abdel Hameed, K. G.;Sender, G.and Korwin-Kossakowska,A.(2007).

Public health hazard due to mastitis in dairy cows. Animal Science Papers and Reports 25 ( 2): 73-85.

46. Beggs, D.S. and Wraight, M.D. (2006). Pilot study parenteral of recently acquired subclinical mastitis during lactation. J. Clin. Microbiol., 84(1-2): 50-2.

47. Tedeschi, G.; Taverna, F.; Negri, A.; Piccinini, R.;Nonnis, S.; Ronchi, S. and Zecconi, A. (2008). Serological proteome analysis of S.aureus isolated from sub-clinical mastitis, J. Dairy Sci., 134(3-4): 388-3891.

48. Persson ,Y.; Nyman, A. K. and Grönlund-Andersson ,U.(2008). Etiology and antimicrobial susceptibility of udder pathogens from cases of subclinical mastitis in dairy cows in Sweden. Acta Veterinaria Scandinavica,( 53):36.

49. Ebrahimi, A. and Taheri, A .M.(2009). Characteristics of staphylococci isolated from clinical and sub clinical mastitis in Shahrekord,Iran. Iran.J.of vet.Rese. , 10 ( 3):, Ser. No. 28,273-277.

50. Sori, H. ; Ademe ,Z., and Sintayehu ,A.(2005). Dairy Cattle Mastitis In and Around Sebeta, Ethiopia. Intern. J. Appl. Res. Vet. Med . 3( 4):2-8.

51. Moret-Stalder, S.; Fournier, C.; Miserez, R.; Albini, S.; Doherr, M.G.; Reist, M.; Schaeren, W.; Kirchhofer, M.; Graber, H.U.; Steiner, A. and Kaufmann, T. (2009). Prevalence study of
Staphylococcus aureus in quarter milk samples of dairy cows in the Canton of Bern, Switzerland. J. Prev. Vet. Med.,( 88): 72-76.

52. Rainard ,P.and Riollet ,C.(2006). Innate immunity of bovine mammary gland. Vet .Res., (37):369-400.

53. Taponen ,S.; Salmikivi, L.; Simojoki ,H.; Koskinen ,MT. and Pyörälä S.(2009). Real-time polymerase chain reaction-based identification of bacteria in milk samples from bovine clinical mastitis with no growth in conventional culturing in milk. J .Dairy Sci.,( 92):26102617

54. Nonnecke, B. J., and K. L. Smith. (1984). Biochemical and antibacterial properties of bovine mammary secretion during mammary involution and at parturition. J. Dairy Sci. (67):2863-2872.

55. Kutila, T., S. Pyorala,H. Saloniemi, and L.Kaartinen. 2003. Antibacterial effect of bovine lactoferrin against udder pathogens. Acta Vet. Scand. 44:35-42.

56. Schukken, Y.H.; Sol, J.;Sampimon, O.C.and Van De Valkengoed, P. (1998).Behandeling van masitis tijdens de lactatie . [treatment of mastitis during lactation]. Page 7-9 in proceeding of Wetenschappelijke vergadering von de Groep Geneeskunde van het Rund , 27 May, de Roskam, Rheden, The Netherlands .

57. Essa ,M.M.( 1992 ) . Coliform mastitis in dairy cattle .Msc. Thesis.Vet. College .Baghdad University , Iraq. 


\section{تثخيص التهاب الضرع البقريالأي تسببه المكورات العنقوديه الذهبيه البقري في

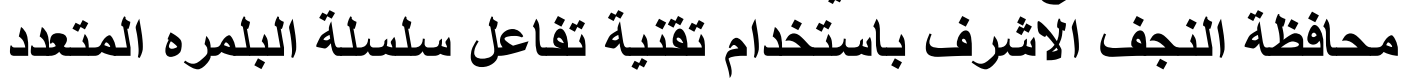

\author{
قاسم حليم كثاش القادي \\ كلية الطب البيطري/ جامعة القادسيه
}

الخلاصة

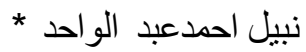

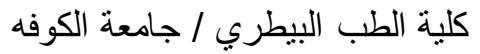

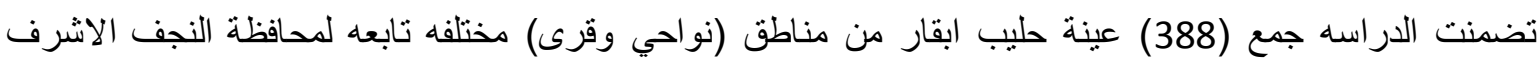

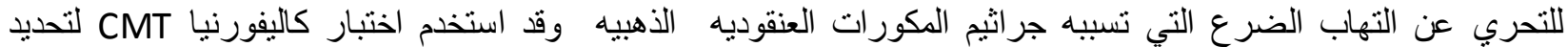

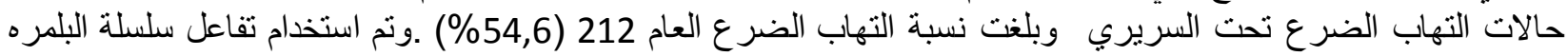

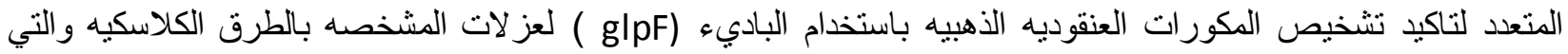

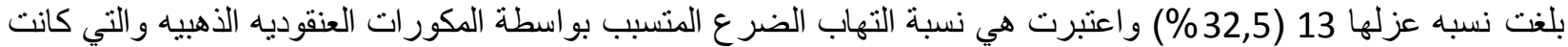

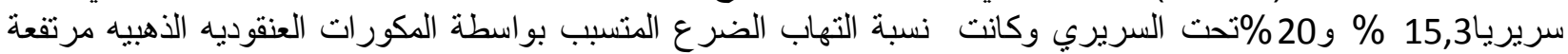
معنويا في الربع الايسر الخلفي مقارنة مع بقية الارباع من الضرع. بحث مستل من رسالة الماجستير للباحث الاول 